\title{
Tadeusz Sierotowicz
}

\section{Schyłek metafory. Rzecz o księdze Natury}

\section{Galileusz i księga natury}

Jeśli przyroda to księga, jej poznawanie to czytanie albo próby jej odczytania. Stąd możliwość interpretacji nauki jako lektury księgi, czyli pewnego tekstu. W konsekwencji, analogicznie do lektury tekstu, wyjaśnianie naukowe to ciągły wysiłek zmierzający do coraz to większej koherencji mającej charakteryzować teoretyczny system nauki, włączając w to i obserwacje. Interpretując każdą nową obserwację, każdy nowy problem jako nowy fragment tekstu, można utrzymywać, iż te odkryte właśnie znaki i linijki „przeczytane”, „wyczytane”, „doczytane”, „odczytane” czy też „sczytane” z kart księgi natury albo i odnalezione między jej

1 Tego rodzaju teoretyzacja poznania naukowego została zaproponowana przez Petera Kosso (1995). Na temat lektury, odczytywania Księgi w ogólności, a księgi natury w szczególności, zob. Maleszyński 1982: 12-15, 31-35. Księga natury jest wistocie rzeczy toposem i w konsekwencji jego analizy o charakterze teoretycznym należą do topiki. W niniejszym artykule rozumiana jest ona natomiast jako metafora, czyli nie w ściśle technicznym znaczeniu loci communes, lecz jako rodzaj motywu, wątku filozoficznego przywolywanego celem ukazania „pewnych fundamentalnych cech zmieniającego się podejścia do nauki” [Pedersen 1992: 20]. Rozróżnienie istotne w świetle tego, co zostanie zaproponowane w zakończeniu niniejszego tekstu, gdzie sugeruje się poszukiwanie nowej metafory [por. też Maleszyński 1982: 37-39]. 
już odczytanymi zdaniami, uzyskują sens jedynie w perspektywie hipotezy dotyczącej tego, co się wydarza w całym dotąd przeczytanym/poznanym opowiadaniu. Rzecz się ma tak, jak z próbami zrozumienia czytanej książki, w których to próbach dotarcie do istoty danego fragmentu zależy od stopnia objęcia przeczytanego dotąd tekstu. Chodzi tutaj o swoistą konfrontację lokalnego i globalnego rozumienia części i całości [Kosso 1995: 161]. Dlatego też można utrzymywać, iż „proces rozwoju nauki oferuje ciągle rozwijający się obraz świata, obraz którego koherencja jest podtrzymywana lub powiększana dzięki ciągłej konfrontacji pomiędzy teoriami i obserwacjami” [Kosso 1995: 158].

Powyższe uwagi szczególnie dobrze przystają do metody rozwiązywania problemów opisanej przez Galileusza, zwanego też Pizańczykiem². Tu zatem zacznijmy opowieść, choć historia metafory księgi natury sięga znacznie bardziej w przeszłość, o czym będzie jeszcze mowa³

Jak wiadomo Galileusz napisał był w Wadze probierczej (Il Saggiatore) następujące, szeroko cytowane słowa:

[...] filozofia zawarta jest w tej przeogromnej księdze, którą ciągle mamy otwartą przed oczami (nazywam tę księgę wszechświatem), jednakże nie można jej pojąć, jeśli wpierw nie pozna się języka, nie pozna się liter, w których została ona napisana. A księga ta została napisana w języku matematyki i jej literami są trójkąty, koła i inne figury geometryczne; bez tych środków niemożliwe jest dla człowieka zrozumienie słowa w niej zapisanego; bez nich udziałem człowieka jest próżne błąkanie się po ciemnym labiryncie. [Galilei 2009: 55]

Na temat Galileusza zob. np. Fantoli 2002, Sierotowicz 2003, Kierul 2012 oraz cytowaną w tych opracowaniach literaturę. Na temat powyższego fragmentu z Wagi probierczej zob. Sierotowicz 2011. Z kolei na temat metody Galileusza zob. Sierotowicz 2013 i cytowaną tam literaturę. Wszystkie dzieła Galileusza w języku oryginalnym były konsultowane i są cytowane wg klasycznej, książkowej edycji Antonio Favara.

3 Metafora jest tropem, w którym „podobieństwo uzasadnia użycie słowa na sposób przenośny zamiast brakującego lub nieobecnego zwrotu dosłownego". Tym sposobem dokonuje się „rozszerzenie znaczenia nazwy poprzez odstępstwo od dosłownego znaczenia słów" [Ricoeur 1988: 236; por. też Kot 2016: 126-141]. 
W cytowanym dziele Galileusz przeciwstawia matematyczny język nauki językowi poezji, literatury i filozofii, zwłaszcza zaś filozofii Arystotelesowej. Rozważania dotyczące tej kwestii Galileusz stylizuje, używając metafory księgi natury określającej nowy sposób pojmowania stworzonego świata. Ale nie czyni tego, szukając metafizycznego ugruntowania poznawalności świata w duchu platonizmu. Galileusz nie podjął bowiem wysiłków zmierzających do głębszej, filozoficznej analizy struktury oraz podstaw teorii naukowej i nie pogłębił refleksji na temat księgi natury.

Jednakże metafora ta głęboko tkwiła w sercu Galileusza ${ }^{4}$. Zapewne w myślach często do niej powracal, w pismach - trochę rzadziej. W liście do Licetiego ze stycznia 1641 roku czytamy, iż księga natury jest „napisana innymi znakami, różniącymi się od znaków naszego alfabetu” - są to bowiem „trójkąty, kwadraty, koła, kule, stożki, piramidy i inne figury matematyczne" [Galilei 1641: 295]. W tym kontekście trzeba, za Eugenio Garinem, podkreślić, że dla Pizańczyka odwołanie się do terminów matematycznych nie jest aluzją do ukrytej duszy rzeczy, natomiast przekładalność, a może lepiej: wyrażalność świata natury za pośrednictwem znaków języka matematyki, nie „wskazuje na jakąś tajemnicę przeciwnie, rozwiewa ją i czyni jawnym to, co było zamknięte i ukryte”. Tym samym rozumienie księgi natury u Galileusza nie opiera się na

[...] liczbach rozumianych jako byty metafizyczne lub jako skamieniałe i wcielone dusze rzeczy. Liczby to doskonałe narzędzie pozwalające na eksplikację relacji i na ścisłe określenie porządku istniejącego pomiędzy pojmowalnymi cechami rzeczy. [Garin 1961: 462]

Tak więc, dodaje Garin, racjonalnej, historycznie usytuowanej i filologicznej interpretacji Pisma Świętego, rozpowszechnionej

4 Jest to jedna z najważniejszych metafor używanych przez Galileusza, w której- by użyć słów Teodora Parnickiego - wyraził on w mowie „zagadnień”, posługując się mową „przedmiotów codziennego użycia”, istotne elementy świata przyrody [zob. Parnicki 1967b: 104]. 
pośród humanistów na miarę Erazma $\mathrm{z}$ Rotterdamu, odpowiada matematyczna lektura przyrody. Jest to istotny moment w historii metafory księgi, albowiem Biblia staje się tekstem retorycznym, zaś przyroda tekstem naukowym, w sensie, w jakim rozumie ten termin Galileusz. I, o ile w pierwszym dominuje pedagogika i sztuka przekonywania, w drugim - rolę nadrzędną pełnią matematyka, obserwacja i dowodzenie [Garin 1961: 463-464].

Galileusz wielokrotnie i w różnych miejscach, także w Wadze probierczej, tę zasadniczą odmienność księgi natury od księgi Objawienia podkreślał. Pierwsza z nich bowiem odznacza się swoistą nieuchronnością, jednoznacznością procesów, druga zaś charakteryzuje się wieloznacznością i otwartością na różne interpretacje. W liście do Benedetto Castellego Pizańczyk napisał:

[...] tak Pismo Święte, jak i przyroda w równym stopniu pochodzą od słowa Bożego: to pierwsze podyktowane przez Ducha Świętego, ta druga zaś jako wierna wykonawczyni Bożych rozporządzeń, jednak Pismo Święte, dostosowując się do powszechnych władz pojmowania, wiele rzeczy wyraża jeśli chodzi o samą formę i o znaczenie słów - w sposób różny od prawdy absolutnej. Przyroda zaś - przeciwnie - jest nieubłagana i niezmienna w zakresie nadanych jej praw i jak gdyby nie troszczy się o nic więcej, jak tylko o swoje ukryte racje i sposoby działania, niezależnie od tego, czy są one rozumiane przez człowieka, czy też nie. [Galilei 2006: 34-35]

Tak więc w nauce jednoznaczność (procesów przyrody) konfrontuje się z wieloznacznością (semantycznie, a może lepiej, lingwistycznie rozumianej wolności człowieka) [por. McMullin 1978: 228-229].

Warto się wczytać dokładniej w metaforę księgi natury, bo jest to chyba intelektualnie najnośniejsza przenośnia, która w sformułowaniu proponowanym w Wadze probierczej służyła i ciągle służy filozofującemu, złudnie głębokiemu myśleniu o nauce i jej relacji (najczęściej) z chrześcijaństwem. Idźmy wpierw tropem myśli Teodora Parnickiego, medytując jego słowami różne style opisu wszechświata. 


\section{Intermezzo: dwa style opisu świata w idiomach Parnickiego}

Do czasów powstania nauki nowożytnej język obejmował (wyrażał) całość wszechświata w ramach jego klasycznego rozumienia (KRW). Znaczenie galileuszowego sformułowania metafory księgi natury zawarte w Wadze probierczej sprowadza się do tego, iż dostrzega się w nim proces podziału KRW na matematyczne i tekstowe rozumienie wszechświata (MRW i TRW). Nim jednak dalsze konsekwencje tego sformułowania przykują uwagę, zatrzymać się trzeba nad pojęciem „wszechświat”, albowiem wprowadzane tutaj rozróżnienia wymagają pełniejszego opisu tego pojęcia.

W powieści Parnickiego Twarz księżyca. Część druga, we wszechświecie (w terminologii Parnickiego „we wszechczasoświecie”) istnieje ilościowa tylko, a nie jakościowa, różnica między przestrzenią i czasem [Parnicki 1967a: 284]. Tłem dla tego pojęcia jest opisywana idea Pierwoziemi i boskości jako pierwoczłowieczeństwa, w ramach którego Chrystus to „Naczelny Mechanik kotłów, wytwarzających parę, władną pokonywać czas, równie jak i przestrzeń” [Parnicki 1967a: 286]. Czas i przestrzeń są jednorodne, a zatem „sposób przestrzeni i czasu opanowywania musi być nie mniej jednorodny, czyli moc, co opanowywanie przestrzeni i czasu umożliwia, tożsama” [Parnicki 1967a: 285]. Mówiąc krótko, możliwe są podróże w czasie, na czym zasadzają się rozważania Maksymiana (jednego z bohaterów powieści), krytykowane przez Rufusa oraz Storacjusza (jego towarzyszy) [Parnicki 1967a: 195-202 i 284-285]. Ściśle rzecz biorąc, Maksymian broni tego poglądu i wykorzystuje go w zawiłej trójrozprawie perypatetycznej, w której stosuje on bardzo przebiegłą technikę retoryczną. Tezy dotyczące Pierwoziemi i tylko ilościowej różnicy pomiędzy bogami a ludźmi okazują się rodzajem argumentu teoretycznego, mającego wesprzeć Juliana Apostatę w jego walce z chrześcijaństwem [Parnicki 1967a: 309-321]. Zostały one spisane przez osobę liczącą na długie lata rządów Juliana (Julian Apostata jest bohaterem powieści Parnickiego Sam wyjdę bezbronny) w apokryficznym i wizjonerskim dwunastoksięgu, przedstawiającym dzieje życia Mitroanii Chorezmijki.

Na marginesie dodałbym, że Parnickiego rozumienie wszechświata zdaje się swoistym skrzyżowaniem greckiej idei kosmosu 
i żydowskiej idei historii jako czasowego wymiaru świata [Heschel 2015: 260]. Nie wchodząc w dalsze szczegóły tych parnickologicznych kwestii, pragnę podkreślić, iż będę określał mianem wszechświata całość czasowych, relacjonalnych i przyczynowych aspektów tego wszystkiego, co istnieje. W tym sensie moje rozumienie wszechświata odpowiada przedmiotowi badań współczesnej kosmologii, czyli „całości” rozumianej jako wszystko to, co znajduje się (lub może się znaleźć) w zasięgu „kompetencji” metody empirycznej [Sierotowicz 1996: 115-118]. Do opisu wszechświata konsekwentnie używa się języka matematyki, poprzez co „dokonuje się $[\ldots]$ idealizacja samej $[\ldots]$ rzeczywistości, ona sama staje się, wyrażając się współcześnie, rozmaitością matematyczną" [Husserl 1987: 19]. Istotnie, na historię kosmologii można patrzeć jak na historię eksploracji przestrzeni rozwiązań równań Einsteina [Sierotowicz 1991: 98 i nn]. Krótko mówiąc, w ramach MRW, bo o takie pojęcie wszechświata tu chodzi, następuje

[...] podstawienie matematycznie podbudowanego świata przedmiotów idealnych za jedynie rzeczywisty świat, rzeczywiście dany doświadczalnie, zawsze doświadczany i dający się doświadczać - nasz zwykły świat życia codziennego. [Husserl 1987: 45]

Wspominane wyżej różne rozumienia wszechświata znakomicie komentują następujące cytaty z Karla Jaspersa:

Niezmierzona twórczość duchowa myśli filozoficznej i teologicznej, która trwa niemal od trzech tysiącleci, jest dla nas nie tylko przedmiotem podziwu. Zawiera bowiem prawdę, którą musimy sobie przyswajać i chronić przed zapomnieniem. Ale w całej naszej postawie myślowej, w uporządkowaniu i strukturze naszego myślenia i poznawania [czyli w ramach KRW, T.S.], dokonała się zmiana, dzięki której wszystko widzimy w nowym świetle. Doszło do niej dzięki wydarzeniu z ostatnich stuleci, które we wcześniejszych wiekach, także u Greków, miało tylko zarodkową formę. Wydarzeniem tym jest nowoczesna nauka [wyłonienie się MRW, T.S.]. [Jaspers 1999: 113] 
Ta nowa odmiana poznania „postępuje naprzód dzięki projektom matematycznym $\mathrm{i}$ ich potwierdzeniu bądź obaleniu za pośrednictwem eksperymentu i obserwacji”. Daje ona wiedzę niepodważalną, powszechnie akceptowaną, ukierunkowaną na wszystko to, „co występuje dla nas w rzeczywistości, co staje się przedmiotem i czym może zajmować się myślenie" [Jaspers 1999: 113-115]. Natomiast o filozofii i teologii (to zasadnicze, obok literatury czy pewnej części historii, elementy TRW) Jaspers pisze:

[... ] między wiarą filozoficzną i wiarą w objawienie zachodzi analogia. Obie mają świadomość źródła, które można tylko rozwijać - którego nie można ani obalać, ani dowodzić argumentami. Podstawa [ich] prawdy nie da się udowodnić. [Jaspers 1999: 235]

Być może z tego powodu hermeneutyka TRW bliższa jest hermeneutyce „koła na piasku”, niż heideggerowskiemu kołu hermeneutycznemu [Heidegger 1994: \$32], zaś dyskretnie aforystyczny charakter prozy Parnickiego jeszcze dobitniej podkreśla niesystemowy, odległy od MRW, charakter $\mathrm{TRW}^{6}$. Znakomitą „metaforą epistemologiczną" [Juszczyk 2004: 163], opisującą złożoną dialektykę łączącą, a właściwiej - dzielącą MRW i TRW oraz wyżej zarysowaną retoryczną kondycję TRW, jest powieść Parnickiego Sam wyjdę bezbronny [Markiewka 1999].

Z fabularnego punktu widzenia powieść Sam wyjdę bezbronny to „domysł na temat zamysłów” [Parnicki 1985: 280] cesarza Juliana Apostaty, który zresztą w latach odpowiadających czasowi powieści powinien był już nie żyć. Palladiusz w pierwszej części tropi owe zamysły na podstawie różnych elementów zbieranych pod-

Zob. np. zakończenie powieści Koła na piasku, gdzie krótki komentarz Spuriosa Lukretiosa zmiata niczym morska fala koło na piasku rysowane $\mathrm{z}$ wielkim przekonaniem i pewnością siebie przez Leptynesa w jego księgach [Parnicki 1989: 254-259].

6 Można by podać wiele przykładów aforyzmów Parnickiego, jak np. ten z Tylko Beatrycze: „[... ] dusza - to tylko Boża o duszy myśl twórcza, utrwalona w ksztalcie cielesnym" [Parnicki 1962: 239]. Są one obecne dyskretnie, choć wyraziście, a to w tym sensie, że nie dominują nad formą, jak to ma miejsce u Nietzschego czy Ciorana (na temat aforyzmów zob. też uwagi Ginzburga [2006: 62-63]). 
czas morskiej, a potem rzecznej, podróży statku „Sucen-Necus”. Jego postępowanie bliskie jest metodom właściwym MRw. Palladiusz opiera się w swym postępowaniu poznawczym na metodzie empiryczno-racjonalnej (obserwuje otaczający świat, analizuje źródła pisane, prowadzi rozmowy). Pośród celów jego poszukiwań należy wymienić dotarcie do dowodu Seleukosa z Seleukii na rzecz hipotezy heliocentrycznej (przeciwko astrologii) oraz odpowiedź na pytanie, jakie są zamierzenia Juliana Apostaty, jeśli chodzi o chrześcijan (tzw. teza cоттAE). Prowadzonym z wielką pasją poszukiwaniom Palladiusza przyświeca ideał opisu „REI oraz zgodności opisu z prawdą PROBATIO” [Parnicki 1985: 183]. Ideał ten pozwala mu na osiągnięcie „spektakularnych wyników”, jak to ujmuje Markiewka [1999: 79], chociaż w ostatecznym rozrachunku nie jest mu dana możność empirycznej weryfikacji swych tez. Natomiast adwersarz Palladiusza, Merkuriusz, zajmuje się systematycznym badaniem „sprawy Palladiusza”, zaś podstawą jego poszukiwań jest cały materiał zawarty w części pierwszej powieści. Analizy snów i interpretacje tekstów są dla Merkuriusza zasadniczymi źródłami poznania rzeczywistości mającej charakter tekstu. Tak więc podstawową metodą poznania jest dla niego hermeneutyka tekstu. Metoda ta zawodzi i Merkuriusz, miast dotrzeć do rozwiązania, napotyka (wytwarza) chaos. Tak więc kamień, spadający podług Palladiusza, w ujęciu Merkuriusza wcale nie spada i może w ogóle nie jest kamieniem7 . Podróż może być zarówno karą wymierzoną mu przez Juliana [Parnicki 1985: 79], jak i własnym przedsięwzięciem Palladiusza, pragnącego odnaleźć dowód Seleukosa [Parnicki 1985: 307].

Ogólnie rzecz biorąc, poznanie prawdy historycznej, w sensie dotarcia do „jedynej wersji wydarzeń”, zdaje się nieosiągalne

7 Wysiłki Merkuriusza spełzły na niczym, ale ten sam los spotkałby każdą inną narrację dotyczącą tego samego tematu, proponowaną jednak przez kogoś innego. Wszak „dziejopisarstwo to baśniopisarstwo” [Parnicki 1978: 293 oraz Parnicki 1989: 62], zaś marzenia o stworzeniu jednoznacznej i dla wszystkich oczywistej wersji zdarzeń w ramach TRW (tak w zakresie pisarstwa dotyczącego dziejów, jak i w zakresie pisarstwa dotyczącego np. filozofii czy teologii) przypominają „marzenie o zapewnieniu trwałości kołu, nakreślonemu laską na piasku nadmorskim" [Parnicki 1989: 118]. 
w ramach TRW. Nieudane wysiłki Merkuriusza dobitnie o tym świadczą, zaś jeszcze dobitniej ilustruje to próba zrekonstruowania pozbawionego rąk i głowy posągu Numy, legendarnego władcy Rzymu, podejmowana przez ojca Palladiusza [Parnicki 1985: 491].

Można zatem zaryzykować tezę, że Sam wyjdę bezbronny to historyczno-fantastyczno-epistemologiczna powieść, będąca metafizyczną metaforą ludzkiej egzystencji. Według tej metafory człowiek, za popełnione przewinienia, jest skazany na podróż, odbywaną w dramatycznych raczej warunkach. Przypomina ona bowiem karę polegającą na zaszyciu skazańca w worku „wraz z licznymi i wężami, i szczurami”. Z tym jednak, że workiem jest „podróż szlakami niewiadomymi, wężami tajemnice i zagadki, a wątpliwości [... ] - szczurami” [Parnicki 1985: 654 i 679]. Ściślej rzecz biorąc, jest to metafora poznawczej sytuacji człowieka. Jak się zdaje, ta ostatnia może przybrać dwojaki kształt.

Człowiek świadom tego, co tropi, z tropiciela może się przemienić w wynalazcę czy odkrywcę [Parnicki 1985: 83]. Nawet jednak tego rodzaju świadomość, czy to na domyśle, czy na innej wiedzy oparta [Parnicki 1985: 6o], nie gwarantuje, ale i nie wyklucza, przekształcenia się domysłu w wiedzę, bo ta, jak niezbity dowód Seleukosa „na rzecz słuszności tezy Arystarcha Samijczyka, iż to Ziemia obraca się wokół Słońca, a nie Słońce wokół Ziemi” [Parnicki 1985: 9-10], niczym skarb zamknięta w opancerzonej skrzyni, leży na dnie jakiejś rzeki czy morza [Parnicki 1985: 315 i Parnicki 1959: 302]. Ta sytuacja poznawcza odpowiada MRW lub temu, co w powieści podpada pod SCIRE [Parnicki 1985: 448].

Jest też i druga sytuacja poznawcza, w której ma się do czynienia z wielością domysłów, ale opancerzona skrzynia nie istnieje. Wówczas sednem sprawy nie jest tropienie czy „szukanie, ile ustalanie, czy i inaczej jeszcze: ocenianie i sądów wydawanie" [Parnicki 1985: 331].Jest to jednak sytuacja trudna do rozwikłania, albowiem wszyscy mogą się tutaj oszukiwać, a to, co dla niektórych jest jasne, innym jawi się jako niemożliwe [Parnicki 1985: 482 i 524 ]. Ta sytuacja poznawcza odpowiada z kolei TRw lub temu, co w powieści podpada pod CREDERE [Parnicki 1985:448].

Całość komentowanej tutaj powieści zdaje się przykładem KRW, w którym najbardziej ceni się „przetwarzanie dziejów w baśń, baśni 
zaś w dzieje" [Parnicki 1985: 212]. To bowiem, co komuś wydaje się dziejami, jest owocem wymysłu (bajki) innych, który to wymysł wprawia w ruch określone wydarzenia (dzieje). Przykładem jest pomysł Stannosa [Parnicki 1985: 347], pragnącego poddać niemal naukowej weryfikacji tezę o wpływie horoskopu na życie ludzi („czy mogą planety na los ludzki wpływać” [Parnicki 1985: 407]). Realizując to zamierzenie, sprawia, że określonej grupie noworodków płci męskiej zostaje postawiony fałszywy horoskop. W grupie tej znajduje się także Palladios. Jego losy życiowe oraz podjęcie wyprawy na statku „Sucen-Necus” zdają się więc dziejami zmagania się z postawionym mu, fałszywym, bo nie jego, horoskopem.

\section{Galileusz o tym, co naprawdę przekonuje}

Powracając do Wagi probierczej i metafory księgi natury, zauważyć należy, iż Galileusz krytykuje TRW (jego wieloznaczność i odwoływanie się do autorytetów), albowiem tylko autorytet osoby, nie zaś dowodzenia i obserwacje, skłania w ramach TRW do przyjęcia takiej, a nie innej lektury danej przenośni. Dowodzenia zaś i obserwacje to zasadnicze środki pozwalające na odczytanie jednoznacznej historii zapisanej w księdze natury. Bo to właśnie ona, księga natury, jest zasadniczą treścią MRW.

Co jednak znaczy owa jednoznaczność i nieuniknioność zjawisk natury czyli fenomenologiczne narzucone unisono wyborów? Myślę, że najlepszą odpowiedź na to pytanie sformułował Bertolt Brecht. Otóż jego Galileusz nosił w kieszeni kamyczek, aby w razie konieczności móc powołać się na zawsze takie same wyniki eksperymentów naukowych:

[... żaden człowiek nie może długo przyglądać się temu, jak upuszczam kamień, mówiąc przy tym: on wcale nie spada. Żaden człowiek tego nie wytrzyma. Pokusa plynąca z dowodu jest zbyt wielka. Ulega jej większość, a w końcu wszyscy. [Brecht 1962: 179]

8 Na temat nieuniknioności zjawisk przyrody, por. sformułowanie Galileusza pochodzące z „czwartego dnia” Dialogu o dwu układach, w którym Pizańczyk 
Wyniki eksperymentów są opisywane w języku matematyki, w tym samym języku są też one projektowane, uzasadniane i w razie konieczności - w oparciu o ten sam język są odrzucane i zastępowane przez inne. Tak jednoznacznie zachodzące procesy rozumie się w ramach MRW.

TRW natomiast obejmuje wszystkie inne dyskursy, w których nie można się odwołać do spadającego kamyczka - albo lepiej: dla tego czy innego teologa, filozofa, historyka, taki kamyczek może istnieć i istnieje. Problem jednak w tym, że nie jest to ten sam kamyczek dla wszystkich, albowiem w filozofii, teologii oraz literaturze wybór i wiara różnią zajmowane przez myślicieli stanowiska. Jasno wyraża to Steiner:

[... ] nieograniczoność dyskursywnej potencjalności ma również swoją negatywną stronę. Niepowstrzymana nieskończoność możliwych do pomyślenia twierdzeń i zdań wywołuje logikę próżni i nihilizmu. [...] „Wszystkie” dowody istnienia czy nieistnienia Boga nie podlegają ochronie przed negacją. W mieście słów jednakowo prawomocne jest przekonanie, że założenie istnienia Boga leży u źródeł ludzkiej mowy i tworzy jej ostateczną dignitas, jak i przekonanie pozytywistów logicznych, że to założenie ma taki sam status jak limeryki. [Steiner 1997: 50]

Albowiem „nie ma takiego pojęcia ani takiej intuicyjnej wizji naszej tożsamości czy relacji ze światem, które nie zawierałoby przynajmniej jednej luki w łańcuchu definicji i twierdzeń” [Steiner 1997: 176].

Można powiedzieć, że Steiner uznaje, iż w każdym dyskursie, w każdym dziele zawarty jest opis jakiegoś fragmentu świata,

pisze o zjawiskach naturalnych w kontekście swojej teorii przypływów morza: „zjawiska te muszą być następstwem ruchów, odpowiadających z przyrodzenia Ziemi, więc nie tylko nie mogą one napotykać na opór i przeszkody, ale muszą się odbywać i następować po sobie nie tylko z łatwością, ale także z koniecznością, tak aby zupełnie niemożliwy był jakiś inny bieg spraw, albowiem takie są własności i warunki rzeczy przyrodzonych i prawdziwych” [Galilei 1953: 455 - wyróż. T.S.]. 
co do realności i prawdy którego autor dzieła jest przekonany, tak jak Galileusz był przekonany co do realności spadania kamienia. Dla odbiorców dzieła to, co ono opisuje, może się stać tak samo oczywiste jak dla autora. Nie wyklucza to jednak tego, że treść utworu może się stać dla odbiorcy przedmiotem rozważań dostrzegających w nim tylko pewną możliwość. W tym drugim przypadku wchodzi się w zakres poetyki przedstawiania wydarzeń, które „mogłyby się zdarzyć, przy czym ta możliwość opiera się na prawdopodobieństwie i konieczności” [Arystoteles, Poetyka, 1451a 36-38]. W konsekwencji w argumentacjach dotyczących interpretacji dzieła z konieczności trzeba się odwołać do retoryki po arystotelesowsku pojętej jako sztuka przekonywania. W obu przypadkach bowiem czytelnik, będący także retorem, ocenia, czy filozoficzna, teologiczna, literacka i (meta)historyczna wizja świata przedstawiona w tekście dzieła (TRW) - o której nie wie, czy jest prawdziwa - jest dostatecznie przekonująca [por. Markiewka 1999: 85]. Człowiekowi bowiem zawsze ten sam przyświeca cel: „prawdy w sidła umysłu poszukującego złowienie” [Parnicki 1967a: 123], i to samo pragnienie nim kieruje: „dociekać, co się naprawdę kryje poza maską budzącą zdumienie" [Parnicki 1959: 10].

\section{Intermezzo wtóre: kilka uwag o historii upadłej metafory}

Galileusz powołując się w Wadze probierczej na księgę przyrody, $\mathrm{z}$ jednej strony wpisuje się $\mathrm{w}$ długą historię znakomicie skonstruowanej metafory ${ }^{9}$, $\mathrm{z}$ drugiej zaś inicjuje proces, lub co najmniej daje wyraz procesowi już istniejącemu, którego esktremizacja doprowadzi do ostrego podziału KRW na MRW i TRW, a w dalszej konsekwencji do przysłonięcia, a właściwie zaćmienia TRW przez MRW. Metafora księgi natury ma długą historię, sięgającą co najmniej czasów Orygenesa i św. Augustyna. Jej historia została opisana przez wielu badaczy i nie tu miejsce na jej powtarzanie. Chciałbym zwrócić uwagę na kilka momentów. Jak się zdaje, to św. Augustyn po raz pierwszy użył sformułowania „księga natury”.

9 Na temat metafory księgi natury i jej historii zob. np. Maleszyński 1982, Blumenberg 1984, Calvino 1995, Harrison 1998 oraz Pedersen 1997 i 2007. 
Ów Ojciec Kościoła metafory tej używa, by pokazać dobroć świata stworzonego przez Boga. Takie podejście pozostaje zgodne z poszukiwaniem vestigio Dei w stworzeniu - aspekt charakterystyczny dla myśli biskupa Hippony.

Pomijając $\mathrm{z}$ braku miejsca niektóre wydarzenia ważne dla historii nauki, takie jak na przykład ponowne odkrycie źródeł greckiej myśli filozoficznej i naukowej, między innymi dzięki tłumaczeniom dokonanym przez badaczy arabskich w Hiszpanii, dzieła Alaina de Lille, Hugona od Św. Wiktora i wielu innych filozofów z XII i XIII wieku, czy też paryskie potępienie 219 błędnych tez dotyczących także i poznania przyrody z 1277 roku, wspomnę tu szczególnie traktat Liber naturae sive creaturarum (1436) Rajmunda Sibiuda, w którym metafora księgi natury rozbłyśnie pełnym światłem. W dziele tym zawarte zostały tezy wprawdzie potępione potem przez Sobór Trydencki, ale dobrze przyjęte przez chrześcijańskich humanistów renesansu. Jedną z nich była teza o tym, że księga stworzenia zawiera wszystkie elementy konieczne do poznania Boga, a także i wszystko to, co niezbędne, aby żyć zgodnie z Jego wolą, dążąc do zbawienia.

Według sygnalizowanych wyżej ujęć metafory księgi natury, spójności i jednolitości przyrody należało się dopatrywać w transcendentnym wymiarze samej przyrody. Przyroda i wszystkie stworzenia są symbolami, zwierciadłami, wyobrażeniami Bożej woli, które manifestują niewidzialne przymioty Bożej mądrości.

W XV i XVI stuleciu następuje istotna zmiana w rozumieniu tej metafory. Pozostaje ona w związku z nowym podejściem do interpretacji Biblii i symbolicznej koncepcji przyrody, które wyłonily się w okresie renesansu i reformy protestanckiej. Otóż, jak się zdaje, filologicznie zorientowana mentalność humanistów i protestantów sprawiła, że w lekturze i interpretacji tekstu biblijnego na pierwszy plan zaczął się wysuwać sens dosłowny czy literalny. Nie mogło to nie doprowadzić do zmiany rozkładu akcentów w ramach „wielowarstwowej” interpretacji Biblii, bowiem na pierwszy plan wysunęły się aspekty filologiczne. Ponieważ jednak alegoryczna lektura Pisma Świętego zakładała specyficzny stosunek do świata przyrody, odejście od tego rodzaju lektury musiało zmienić sposób myślenia o naturze. Upraszczając, można powiedzieć, że uznano, iż 
tylko słowa, a nie przedmioty natury, mają jakąś referencję, dlatego też materialnym przedmiotom świata przyrody przestano przypisywać jakiekolwiek wykraczające poza nie znaczenie. Otworzyło to drogę nowemu podejściu do badań przyrodniczych, wyzwalając je z niewoli religijnych konotacji. Opisywany proces przemian w rozumieniu metafory księgi przyrody celnie syntetyzuje Aldous Huxley, pisząc, że „w erze nauki, świat nie może być widziany jako zbiór symboli, wskazujących poza ten świat”. I dalej: „świat jest pełen poezji, lecz oznacza tylko siebie samego" [Huxley 1963: 111].

Galileuszowe ujęcie wpisuje się w takie właśnie rozumienie księgi przyrody. W ogólności metafora księgi natury służy Galileuszowi do argumentacji na rzecz tezy, że przyroda, w odróżnieniu od wieloznacznych tworów fantazji literackiej dotyczących kwestii naturalnych, jest jednoznaczna i nieubłagana w swym zdarzaniu się. W konsekwencji lektura księgi przyrody winna prowadzić do jednoznacznych odpowiedzi, które są prawdziwe albo fałszywe. Rzecz jasna, nie ma tu żadnego automatyzmu, w tym sensie, że nawet posługując się językiem matematyki, nie otrzymuje się od razu gotowych rezultatów. Być może to właśnie miał na myśli Galileusz, kiedy pisal, że „nam jednak wypada zadowolić się znikomością tego, co możemy pośród cieni, po omacku niejako, odgadnąć” [Galilei i Guiducci 1619: 98-99].

\section{Zakończenie - jeśli nie Księga, to co w zamian?}

Galileusz, pozostając w nurcie dokonujących się zmian, przesuwa jakby metaforę księgi przyrody z kontekstu teologicznego (gdzie miała ona swoje metaforyczne, a może i trochę apologetyczne, znaczenie) do kontekstu, powiedzielibyśmy dzisiaj, metodologicznego. Jest to doniosła zmiana, bowiem inicjuje trajektorię prowadzącą do konkluzji, że istotnych informacji o świecie dostarcza tylko i wyłącznie nauka (= księga natury) i że tylko jej lektura jest znacząca, albowiem jej tekst pozostaje jednoznaczny. W tym sensie staje się też ideałem wszelkiej lektury, ideałem poznania pewnego. Księga Objawienia, wieloznaczna, dyskusyjna, czasem niejasna, staje się tekstem coraz bardziej literackim i jako taka, poznawczo rzecz biorąc, schodzi na drugi plan, przyćmiona bla- 
skiem księgi natury i bezdyskusyjnej, wzorcowej „naukowości” jej lektury. Można odnieść wrażenie, że księga przyrody stała się księgą fundamentalną, sugerując, iż przyroda jest wszystkim tym, co realne, a dotyczące jej dane są ostatecznymi i najbardziej podstawowymi danymi [por. Heschel 2015: 265-266]. Ewolucja roli i znaczenia metafory księgi natury dokumentuje ewolucję roli i znaczenia nauki w mentalności współczesnego człowieka [por. np. Steiner 1997].

Nic w tych przemianach dziwnego - taki jest los metafor, zwłaszcza tych, które miały do czynienia z niebem. Jak zauważa Józef Tischner, „gdy metafory powracają na ziemię po odegraniu swych ról w niebie, mogą znaczyć coś innego niż przedtem i coś innego opisywać. Metafory stają się kapryśne, opisują świat wybiórczo". To właśnie stało się udziałem metafory księgi natury zaczęła opisywać świat wybiórczo, to jest tak, jakby w niej, i tylko w niej, można było wyczytać to, co jednoznaczne, oczywiste, bezdyskusyjne i realne [Heschel 2015: 180-181]. Doprowadziła do myślenia, „którego celem i racją jest bezwzględna afirmacja aktualnego świata” poprzez realizm i zasadę „ścisłej jednoznaczności języka" [Tischner 2011b: 523 i 526].

Ale nie tylko to. Oto bowiem księga natury, widziana jako metafora nauki, a szerzej - poznania, wiedzie nieprzygotowanego czytelnika na manowce. Zwodzi, może trochę tak jak piękno, o czym przypomniał ostatnio Stefan Chwin [Chwin 2016]. Mechanizm zwodzenia, a może uwodzenia, jest bardzo prosty. Galileusz uczył, iż by móc księgę natury czytać, trzeba znać język matematyki. Obecnie jest to język niesłychanie skomplikowany, dostępny dla niewielu [Blumenberg 1984: 76]. Kto go nie zna, może tylko wierzyć, że lektura księgi przyrody dokonywana przez wtajemniczonych jest wiarygodna. To jednak wiara, która opiera się na zaufaniu wobec władających językiem matematyki. Stąd przymiotnik „naukowy” stał się rodzajem retorycznego, a czasem i erystycznego argumentu na rzecz poprawności głoszonych tez, stąd też i to, że obok wiary w naukowość krzewi się irracjonalizm w myśleniu o przyrodzie. Być może taki właśnie jest sens zwierzeń Serenusa Zeitbloma, który medytuje nad mową natury, pytając czy chodzi „tutaj o jakieś tajne pismo”, jakby musiała się ona posługiwać 
[...] własną, z niej samej zrodzoną, zorganizowaną mową? Jakąż bowiem spośród tych, które wynaleźli ludzie, miałaby wybrać, aby siebie wyrazić? Już wówczas $[. .$.$] pojąłem bar-$ dzo wyraźnie, że pozaludzka natura z samej istoty rzeczy jest illiterata, co w moich oczach zresztą stanowi właśnie o jej niesamowitości. [Mann 2008: 22]

Biorąc pod uwagę zarysowaną wyżej sytuację, można za Paulem Ricoeurem powiedzieć, iż metafora księgi natury przestała być metaforą żywą [Ricoeur 1976 i Beardsley 1981]. Stała się raczej ornamentem myśli, stereotypem wyobrażeniowym, wręcz argumentem erystycznym [Folsom 2011]. Dlaczego tak się stało?

Tischner utrzymywal, iż swoistość stylu myślenia zależy od tego, „skąd ono płynie”. Istotnie, „filozofowie przemawiają z takich miejsc w świecie, z jakich nikt inny nie mówi - ani poeta, ani kaznodzieja, ani uczony uprawiający nauki pozytywne" [Tischner 2o11b: 511; por. też Heschel 2015: 22-23]. Filozof przemawia z głębi radykalnej niepewności wobec nieabsolutnego świata, kaznodzieja/ bogoznawca [Parnicki 1967b: 118] przywraca sens rzeczywistości, wsłuchując się w niepowtarzalny głos Objawienia dający absolutny punkt odniesienia [Miłosz 2002: 63 i Heschel 2015: 255-256], czyli odpowiadając na pytanie, czego Bóg od nas wymaga [Heschel 2015: 215], zaś uczony, uzbrojony w szkiełko i wagę, z wysokości już osiągniętej wiedzy dalszej, jednoznacznej pewności w kwestiach „błahych” szuka ${ }^{10}$. Naturalnie każde z tych miejsc, z których przemawiają filozof, kaznodzieja czy naukowiec, prowadzi do różnych kryteriów uzasadnienia i sprawdzania dyskursów. Istotnie, za Tischnerem można powiedzieć, iż pluralizm stylów myślenia

[... ] dopuszcza możliwość wielu typów racjonalności, z których każdy odnosi się do określonej dziedziny rzeczywistości,

10 „Do o[jca] Camp[anelli]. Wyżej sobie cenię dotarcie do prawdy, nawet w kwestii błahej, niż długie dysputy w najwyższych kwestiach, bez osiągnięcia żadnej prawdy”. Uwaga zapisana ręką Galileusza na marginesie komentarza będącego odpowiedzią na jego traktat Discorso intorno alle cose che stanno in su l'acqua o che in quella si muovono [Galilei 1612: 738]. Na temat różnych dróg do prawdy por. też uwagi Parnickiego [1959: 587]. 
i konsekwentnie [... ] wielu nauk, odznaczających się własnym rodzajem racjonalizmu. [Tischner 2011a: 479-480; por. też Sierotowicz 2002]

Różny też jest nastrój towarzyszący narodzinom odmiennych stylów myślenia [por. Heidegger 1994: \29]. Filozof żyje dramatem i cierpieniem radykalnej niepewności, naukowiec gnany jest ciekawością, bogoznawcę z kolei przenika bojaźń i strach [por. Tischner 2011b: 514-515 i Heschel 2015: 97-100].

A ponieważ, jak zauważa Tischner, „metaforyczne stało się samo myślenie" [Tischner 2011b: 510], zapytać trzeba, w jakim miejscu zrodziła się metafora księgi natury. Schematycznie rzecz ujmując, powiedzieć można, iż metafora ta dominowała w myśleniu, rozwijająca się tam, gdzie podejmowana była próba odpowiedzi na pytanie o miejsce człowieka i świata w biblijnej narracji [por. Heschel 2015: 31]. Jednakże w miarę upływu czasu księga natury przysłoniła wszystkie inne księgi, zwłaszcza księgę Objawienia, jak to zostało wyżej zilustrowane. Zwyciężyło, by użyć tutaj niezwykle trafnej diagnozy Michela Houellebecqa, charakterystyczne dla myśli zachodniej poszukiwanie pewności poznania racjonalnego. Tak to ujmuje autor Ulegtości:

[...] żadna potęga ekonomiczna, polityczna, społeczna czy religijna nie potrafi stawić czoła oczywistości istnienia racjonalnej pewności. Można powiedzieć, że Zachód interesował się ponad miarę filozofią i polityką, że prowadzil, w sposób całkowicie pozbawiony rozsądku, debaty filozoficzne i polityczne; można też powiedzieć, że Zachód odczuwał prawdziwą namiętność do literatury i sztuki; lecz w gruncie rzeczy nic nie liczyło się w jego historii tak, jak potrzeba racjonalnej pewności. Dla owej potrzeby Zachód poświęcił właściwie wszystko: religię, szczęście, nadzieję i w końcu życie. [Houellebecq 2015: 336-337]

Zachód niełatwe chwile przeżywa, dlatego też warto powrócić do miejsca, w którym powstała metafora księgi natury. Warto podjąć to samo pytanie o miejsce człowieka i świata opisywanego 
przez nauki doświadczalne w graniach rzeczywistości widzianej $\mathrm{w}$ innych kontekstach poznania, niekoniecznie identyfikujących standardy akceptowalności poznawczej z tym, co mierzalne, obliczalne, doświadczalne i powtarzalne. Jak i gdzie szukać metafory żywej, która, tak jak swego czasu metafora księgi natury, mogłaby stworzyć „układ odniesień konstytuujący światowośc” [por. Heidegger 1994: 125] w odniesieniu do narracji biblijnej w sposób nowy, inspirujący i twórczy? Która nie byłaby zasłaniającym murem, lecz okazała się oknem otwartym na nowe pejzaże [por. Heschel 2015: 148]?

Tego rodzaju metafora winna może przypomnieć wieloznaczność słowa. Przywołanie faktu, iż słowo zależnie od kontekstu zmienia znaczenie, mogłoby otworzyć nowe drogi. Jak pisze Abraham Joshua Heschel, „złoto dla kupca oznacza bogactwo, złotnik widzi w nim materię pierwszą do wyrobu klejnotów, technik nierdzewny materiał, łatwo kowalny i posiadający określony ciężar własny, zaś retor widzi w nim dobroć, kiedy rozprawia o «złotym sercu»” [por. Heschel 2015: 226]. Tego rodzaju wieloznaczność dobrze odpowiada tym fragmentom Księgi Psalmów, w których Boże działanie porównywane jest do śladów zostawionych na wodzie (Ps 77 (76), 20), zaś Jego słowu przypisuje się wielość znaczeń (por. Ps 62 (61), 12). Taka może jest biblijna racja tego, że „nie pojmie człowiek dziel, jakich Bóg dokonuje od początku do końca” (Koh 3, 11). Rodzi to w człowieku specyficzną dla jego natury hermeneutyczną orientację, przejawiającą się w tym, iż

[... nigdy nie przestaliśmy i prawdopodobnie nigdy nie zaprzestaniemy stawiać podobnych pytań [dotyczących sensu; T.S.]. I nigdy nie pozbędziemy się pokusy postrzegania świata jako tajemnego szyfru, do którego uparcie usiłujemy znaleźć klucz. [Kołakowski 1990: 119]

I jeszcze jeden element do nowej metafory. W moim pojęciu rabin Jonathan Sacks [Sacks 2016] ma rację, kiedy twierdzi, że nawet jeślibyśmy rozszyfrowali i odczytali wszystkie naukowe zagadki przyrody, to i tak nie zrozumielibyśmy umysłu Boga. Istotnie, o Bogu więcej mówi ból matki i ojca akceptujących 
wybory buntowniczych dzieci, niż wszystkie równania teorii fizycznych.

Naturalnie miejsce, z którego nieśmiało głoszone są wyżej zarysowane dyskursy, nie jest ani teologicznym, ani filozoficznym, ani też naukowym. To raczej miejsce, z którego przemawia poeta. Miejsce, w którym przekuwa się na słowa różnie doświadczane „Wszystko, wcale nieźle nic przesłaniające” [za: Szymborska 1995: 14], będące nie tyle odpowiedzią, co pytaniem o wszystko obejmujący sens [Heschel 2015: 139-141]. Jest to miejsce, w którym rodzi się narracja, teoria, idea, niepowtarzalne połączenie non sequitur inaczej odseparowanych obszarów poznania, takich jak naukowe, teologiczne czy filozoficzne. Krótko - miejsce, albo może lepiej, wydarzenie [Heschel 2015: 263-266] - w którym powstaje wizja świata określająca hierarchię wartości efektywnie akceptowaną przez człowieka, inspirującą jego działanie, nadającą sens i wyrażającą przeznaczenie ludzkiej egzystencji [zob. Sierotowicz: 1997].

\section{Coda}

Napisałem powyższe słowa, nie żeby nową metaforę już „poznaną utrwalić, tylko by ku metaforze, której jeszcze nie znam, zacząć podążać” [parafraza zdania z: Parnicki 1959: 203]. Nową metaforę, której historię warto, należy, trzeba zacząć opowiadać, ażeby wieszczącym zmierzch przepowiedniom Houellebecqa została przeciwstawiona ożywcza alternatywa nowych idei i metafor. Trzeba odwrócić stronę i zacząć pisać nowy rozdział historii idei. Wszak, jak podkreślał Jorge Luis Borges, historia powszechna to być może historia kilku metafor [Borges 1976], zaś „księga, projektor całości semiotycznej, sama ulega wciąż powracającym koniunkturom” [Maleszyński 1982: 19].

\footnotetext{
Skróty

KRW - klasyczne rozumienie wszechświata

MRW - matematyczne rozumienie wszechświata

TRW - tekstowe rozumienie wszechświata
} 


\section{Bibliografia}

Beardsley Monroe C. (1981), Aesthetics, problems in the philosophy of criticism, Hackett Publishing Company, Indianapolis [Stany Zjednoczone].

Blumenberg Hans (1984), La leggibilità del mondo. Il libro come metafora della natura, il Mulino, Bologna [Włochy].

Borges Jorge L. (1976), Kula Paskala [online], Warszawa [dostęp: 24 maja 2016], http://bazhum.muzhp.pl/media//files/ Teksty_teoria_literatury_krytyka_interpretacja/Teksty_teoria_ literatury_krytyka_interpretacja-r1976-t-n2_(26)/Teksty_teoria literatury_krytyka_interpretacja-r1976-t-n2_(26)-s177-185/Teksty_ teoria_literatury_krytyka_interpretacja-r1976-t-n2_(26)-s177-185.pdf.

Brecht Bertold (1962), Życie Galileusza, w: tegoż, Dramaty, red. Konrad Gajek, Ossolineum, Wrocław.

Calvino Italo (1995), Il libro della natura in Galileo, w: tegoż, Saggi 1945-1985, Mondadori, Milano [Włochy], s. 853-86o.

Chwin Stefan (2016), Zwodnicze piękno, Biblioteka Tygodnika Powszechnego, t. Ix, Kraków.

Fantoli Annibale (2002), Galileusz, przeł. Tadeusz Sierotowicz, BIBLos, Tarnów.

Folsom Marty (2011), The Two Books Metaphor - a Critique and a Caution, „Crux”, z. 47, s.31-37.

Galilei Galileo (1612), Discorso intorno alle cose che stanno in su l'acqua o che in quella si muovono, w: Le Opere di Galileo Galilei: Edizione Nazionale, red. Antonio Favaro, Tipografia G. Barbèra, Firenze [Włochy], 1929-1939, t. IV, s. 3-286.

Galilei Galileo, Guiducci Mario (1619), Discorso delle comete, w: Le Opere di Galileo Galilei: Edizione Nazionale, red. Antonio Favaro,

Tipografia G. Barbèra, Firenze [Włochy], 1929-1939, t. VI, s. 37-108.

Galilei Galileo (1641), Lettera a Fortunio Liceti (Listo do Fortunia Licetiego), w: Le Opere di Galileo Galilei: Edizione Nazionale, red. Antonio Favaro, Tipografia G. Barbèra, Firenze [Włochy], 1929-1939, t. XVIII, s. 294-295.

Galilei Galileo (1953), Dialog o dwu najważniejszych układach świata, Ptolemeuszowym i Kopernikowym, przeł. Edward Ligocki, PwN, Warszawa.

Galilei Galileo (2006), Listy kopernikańskie, przeł. Robert Bellarmin, Adam Adamski, Bıblos, Tarnów.

Galilei Galileo (2009), Waga probiercza, przeł. Tadeusz Sierotowicz, BIBLOS, Tarnów. 
Garin Eugenio (1961), La nuova scienza e il simbolo del 'libro', w: tegoż,

La cultura filosofica del rinascimento italiano, Sansoni, Firenze

[Włochy], s. 451-465.

Ginzburg Carlo (2006), Tropy. Korzenie paradygmatu poszlakowego,

„Zagadnienia Filozoficzne w Nauce”, z. 39, s. 8-65.

Harrison Paul (1998), The Bible, Protestantism, and the Rise of Natural

Science, Cambridge University Press, Cambridge [Wielka Brytania].

Heidegger Martin (1994), Bycie i czas, przeł. Bogdan Baran, PWN, Warszawa.

Heschel Abraham J. (2015), Bóg szukający człowieka, przeł. Albert Gorzkowski, Wydawnictwo Esprit, Kraków.

Houellebecq Michel (2015), Cząstki elementarne, przeł. Agnieszka Daniłowicz-Grudzińska, Grupa Wydawnicza Foksal, Warszawa.

Husserl Edmund (1987), Kryzys nauk europejskich i fenomenologia transcendentalna, przeł. Sławomira Walczewska, PAT, Kraków.

Huxley Aldous (1963), Literature and Science, Leet's Islands Book,

New Haven [Stany Zjednoczone].

Jaspers Karl (1999), Wiara filozoficzna wobec Objawienia, przeł. Grzegorz Sowiński, Znak, Kraków.

Juszczyk Andrzej (2004), Retoryka i poznanie. Powieściopisarstwo Teodora Parnickiego, Universitas, Kraków.

Kierul Jerzy (2012), Galileusz, PIw, Warszawa.

Kołakowski Leszek (1990), Orrore metafisico, il Mulino, Bologna

[Włochy] (tłum. polskie: Horror metaphysicus, Res Publica, Warszawa 1990).

Kosso Peter (1995), Leggere il libro della natura. Introduzione alla filosofia della scienza, il Mulino, Bologna [Włochy].

Kot Dobrosław (2016), Myślenie dramatyczne, Copernicus Center Press, Kraków.

Maleszyński Dariusz Cezary (1982), „Jedyna księga”. Z dziejów toposu w literaturze dawnej, „Pamiętnik Literacki”, z. 73(3/4), 3-39 [online, dostęp: 10 kwietnia 2017], http://www.bazum.muzhp.pl.

Mann Thomas (2008), Doktor Faustus, przel. Maria Kurecka, Muza, Warszawa.

Markiewka Tomasz (1999), Poznanie w powieści, w: Świat Parnickiego, red. Jacek Łukasiewicz, Towarzystwo Przyjaciół Polonistyki Wrocławskiej, Wrocław, s. 76-85.

McMullin Ernan (1978), The Conception of Science in Galileo's Work, w: New Prospectives on Galileo, red. Robert E. Butts i Joseph C. Pitt, D. Reidel Publishing Company, Dordrecht [Holandia], s. 209-257. 
Miłosz Czesław (2002), Traktat teologiczny. 1. Takiego traktatu, w: tegoż, Druga przestrzeń, Znak, Kraków.

Nowakowska Alicja (1999), Przyroda w powieści „Srebrne orty”, w: Świat Parnickiego, red. Jacek Łukasiewicz, Towarzystwo Przyjaciół Polonistyki Wrocławskiej, Wrocław, s. 172-175.

Parnicki Teodor (1959), Stowo i ciało, Pax, Warszawa.

Parnicki Teodor (1962), Tylko Beatrycze, Pax, Warszawa.

Parnicki Teodor (1967a), Twarz księżyca. Część druga, Pax, Warszawa.

Parnicki Teodor (1967b), Twarz księżyca. Część trzecia, Pax, Warszawa.

Parnicki Teodor (1978), Śmierć Aecjusza, Pax, Warszawa.

Parnicki Teodor (1985), Sam wyjdę bezbronny, Pax, Warszawa.

Parnicki Teodor (1989), Koła na piasku, Pax, Warszawa.

Pedersen Olaf (1992), Księga natury, przeł. Włodzimierz Skoczny,

„Zagadnienia Filozoficzne w Nauce”, z. 14, s. 19-50.

Pedersen Olaf (1997), Konflikt czy symbioza, przeł. Włodzimierz Skoczny, BIBLos, Tarnów.

Pedersen Olaf (2007), The Two Books. Historical notes on Some

Interactions Between Science and Theology, Libreria Editrice Vaticana, Città del Vaticano [Watykan].

Preti Giulio (1974), Retorica e logica. Le due culture, Einaudi, Torino [Włochy].

Ricoeur Paul (1976), Interpretation theory: discourse and the surplus of meaning, Texas Christian University Press, Fort Worth [Stany Zjednoczone].

Ricoeur Paul (1988), Metafora i symbol, przeł. Katarzyna Rosner, „Literatura na Świecie”, z. 8-9, s. 233-254.

Sacks Jonathan (2016), The Closeness of God (Ki Tissa 5776) [online], Londyn [dostęp: 16 sierpnia 2016], http://www.rabbisacks.org/thecloseness-of-god-ki-tissa-5776.

Sierotowicz Tadeusz (1991), O pewnym problemie kosmologii wspótczesnej $w$ kontekście sporu o uniwersalia, w: Spór o uniwersalia a nauka wspótczesna, red. Michał Heller, Włodzimierz Skoczny, Józef Życiński, Ośrodek Badań Interdyscyplinarnych (овI) - Wydział Filozofii pAt, Kraków, s. 87-108.

Sierotowicz Tadeusz (1996), O modelach $w$ kosmologii, w: Przestrzenie księdza Cogito. Księdzu Michałowi Hellerowi w sześćdziesiątą rocznicę urodzin, red. Stanisław Wszołek, BIBLOs, Tarnów, s. 114-135.

Sierotowicz Tadeusz (1997), Nauka a wiara - przestrzeń dialogu, BIBLOs, Tarnów.

Sierotowicz Tadeusz (2002), Nauka a wiara - przestrzeń dialogu. Postscriptum, „Zagadnienia Filozoficzne w Nauce”, z. 31, s. 3-44. 
Sierotowicz Tadeusz (2003), Galileusz, wAM, Kraków (drugie wydanie dostępne jest w profilu autora na stronie Academia.edu).

Sierotowicz Tadeusz (2011), Galileuszowe ćwiczenia z retoryki i dialektyki. Ćwiczenie drugie: swada o księdze, „Zagadnienia Filozoficzne w Nauce", z. 48, s. 46-76.

Sierotowicz Tadeusz (2013), O położeniu plam słonecznych, BIBLOs, Tarnów.

Steiner George (1997), Rzeczywiste obecności, przeł. Ola Kubińska, słowo/obraz terytoria, Gdańsk.

Szymborska Wisława (1995), Rzeczywistość wymaga, w: tejże, Koniec i początek, Wydawnictwa a5, Poznań.

Tischner Józef (2011a), Labirynty racjonalizmu, w: tegoż, Myślenie wedtug wartości, zNAK, Kraków, s. 475-483.

Tischner Józef (2011b), Myślenie z wnętrza metafory, w: tegoż, Myślenie wedtug wartości, ZNAK, Kraków, s. 510-526.

Uniłowski Krzysztof (1999), Parnicki - między poznaniem a pisaniem (na przykładzie „Sam wyjdę bezbronny”), w: Świat Parnickiego, red. Jacek Łukasiewicz, Towarzystwo Przyjaciół Polonistyki Wrocławskiej, Wrocław, s. 66-75.

\section{Tadeusz Sierotowicz}

\section{The autumn of the metaphor. A case of the Book of Nature}

The book of nature expressed both the possibility of knowing/reading of nature and the relationship between the experimental science and other books, mainly the book of Revelation. However, the role and significance of the metaphor changed with the development of natural science, and now the book of nature seems to obscure other books, and, moreover, its reading became the model of reading in general. Actually this metaphor is not a living metaphor any more, as it does not create, but closes and eclipses. Hence the need to look for a new one. This story is told here on the basis of Teodor Parnicki's prose, who was a very careful observer and connoisseur of history of ideas, and of history as a mode of literature.

Keywords: topics, metaphor, the book of nature, Teodor Parnicki, polysemy of a word

Tadeusz Sierotowicz - ur. 1960 w Nowym Sączu, dr hab., zajmuje się filozofią nauki, zwłaszcza w aspekcie jej relacji z teologią, literaturą oraz dydaktyką matematyki i fizyki. Tłumacz literatury filozoficznej. Autor publikacji doty- 
czących Galileusza i tłumacz jego dzieł na j. polski. Współpracuje z Centrum Kopernika Badań Interdyscyplinarnych w Krakowie oraz z Istituto di Scienze Religiose w Bolzano (Włochy). Opublikował m. in. Nauka a wiara - przestrzeń dialogu, Tarnów 1997 (poszerzona i poprawiona wersja polska książki La casa nel mondo interpretato, Città del Vaticano 1995; wydanie drugie poprawione w profilu: Academia.edu), Od metodycznej polemiki do polemiki metodologicznej. Impresje z lektury „Wagi probierczej” Galileusza wraz $z$ antologia, Tarnów 2008 (wydanie drugie, poprawione i zmienione, zatytułowane Aut Ceasar aut nihil, jest dostępne pod adresem internetowym: https://isr.academia.edu/TadeuszSierotowicz/Books), O położeniu plam słonecznych, Tarnów 2013 oraz tłumaczenie dzieła Galileusza Waga probiercza, Kraków-Tarnów 2009 oraz esej: Fenomenologia del metodo investigativo. L'abduzione e il metodo di Monsieur Poirot (http://www.griseldaonline.it/ camporesi/cinema/abduzione-e-metodo-di-monsieur-poirot.html; czasopismo online Wydziału Filologii Klasycznej i Italinistyki Uniwersytetu w Bolonii; publikacja: 30/o6/2017). Obecnie przygotowuje włoską edycję Filozofii dramatu ks. prof. J. Tischnera oraz esej na temat filozofii dramatu jako filozoficznej tradycji badawczej w ujęciu L. Laudana. Profil w: Academia.edu. E-mail: sierotowicz@gmail.com. 